\title{
Political psychology of Indonesian political figure: A case study of a political entrepreneur who is not hesitant in paving a new way
}

Abraham, Juneman

Department of Psychology, Bina Nusantara University, Indonesia (juneman@binus.ac.id)

Prayoga, Tommy

Department of Psychology, Bina Nusantara University, Indonesia (ygtommyoung@ gmail.com)

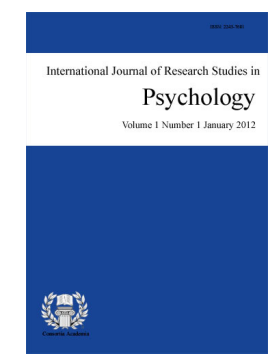

ISSN: $2243-7681$ Online ISSN: 2243-769X

OPEN ACCESS

Takwin, Bagus

Faculty of Psychology, Universitas Indonesia, Indonesia (bagus-t@ui.ac.id)

\section{Abstract}

An understanding of the personal history of political figures and a disclosure of the social motives behind the public action of a political figure are essential to improve the quality of the citizen's political vote. A comprehensive and balanced analysis is required in this context, and political psychology could play a pivotal role. However, in Indonesia, such efforts are still relatively rare. This study contributes by conducting a case study on a political figure $(n=1)$, Surya Paloh. The method of personality measurement at a distance was used to compose profile of Surya Paloh with the following arrangements: (1) General psychobiography, (2) Beliefs and reasoning patterns, (3) Cognitive aspects, (4) Social motives, (5) Personality traits, and (6) Leadership Competency, each with its strengths and risks. This research concludes that Surya Paloh is a political entrepreneur, with high neuroticism, high excitement seeking, low compliance, and high achievement striving.

Keywords: political psychology; entrepreneur; idealist; psychohistory; Indonesia 


\section{Political psychology of Indonesian political figure: A case study of a political entrepreneur who is not hesitant in paving a new way}

\section{Introduction}

A couple months ago, two members of the National Democratic Party (Partai Nasdem) have been questioning the effort to bring Setya Novanto back to being the Head of People's Representative Council of Indonesia (DPR RI) (Tashandra, 2016a). Head of the party's central board (DPP), Lutfhi A. Mutty questioned the morality of this discourse because Novanto previously resigned from the position due to an allegation of huge scandal involving extortion (Jensen \& Asmarini, 2015); while fraction secretary Syarif Abdullah expressed that it does not matter who is in charge, as long as the credibility and morality are accountable (Tashandra, 2016b). The best virtue to describe the party is their self-proclaimed morality. Before condoning as a party, Nasdem was not a political rather a mass/community organization (Ormas). Its main purpose is to restore Indonesia to be a nation with full sovereignty over politics, economy, and culture (Eksan, 2011) The man behind its bold and unique standpoint is no other than politician-mediapreneur, Surya Dharma Paloh (Figure 1; Asril, 2016).

At this time and age, politics and economics are two of the most important elements in developing country like Indonesia. Not to oversimplify, but whomever the nation pick to play a role in the two sectors practically determine the fate of the entire country. We can't really pick our businessmen, but we have all the power to pick our politicians. The people decide who they think should be in power, to lead and protect them in return.

Recent rising political tensions have proven so. First, messy capital governor election divided the nation in two, the ex-Education Minister Anies 'Anies' Baswedan voters versus Christian-then-governor Basuki 'Ahok' Tjahaja Purnama voters. We were forced to pick between "religion" and "tolerance". Second, Indonesia's Corruption Eradication Commission (Komisi Pemberantasan Korupsi Republik Indonesia) has finally been facing their biggest opponent in the light of the country, i.e. the People's Representative Council (DPR), as the latter tries to possess the right to intervene over the former, and even disband them. On the first case, not all Anies voters chose him because of his religion. Anies' politeness, charisma, and wit charmed the voters greatly, convincing them that he can do a better job than other candidates. There were also Muslims who preferred Ahok, as he has proven himself in establishing a more structured capital of Indonesia. However, deemed impolite and offensive, he was perceived as an unfit leader to many. Many considered Ahok as logical and bold, while Anies is more assertive and patient. The authors sincerely believe that the two has their own quality and same purpose, and are not trying to defend or defame any of them. Rather, this short passage is to prove a point that Indonesian picks their leaders based not only from their work, but also heavily on personal characteristics, from religion (cf. Abraham \& Rufaedah, 2014), behaviors, way of thinking, and even traits. Every debate was evaluated based on not only the content and issues, but also how the candidates are speaking, facial expression, tone, and approach to other candidates. Sometimes, these things account way more than the previous and current fruit of works of the two.

Although most politician's media appearance are organized and guided by a series of well-thought PR (public relation) techniques, politicians, along with their own vision of what's best for the people, differ in terms of behavior and approach to issues. This is good for democracy, although it requires the people to get to know the politicians deeper. Not only from overt behavior but also from covert cognitive pattern and personality traits. These are what the researcher trying to uncover, the cognitive and personality aspect of a politician. The cognitive pattern here refers to the pattern of thinking and approach towards an issue at hand, whether it is personal or public-related. The cognitive pattern here encompasses a leader's ability to think strategically. Thus, it requires (and also reflect) a leader's effort to amass cultural and environmental elements to formulate strategy and address problems (Dragoni, Oh, Tesluk, Moore, VanKatwyk, \& Hazucha, 2014). This unique cognitive style is consistent from time to time and shows how individuals prefer to take, process, organize and use information 
(Jain \& Jeppesen, 2013). Silvester, Wyatt, and Randall (2014) found out that cognitive ability determines competence, thus is very important in determining the performance of a politician. How this is understood by the people is crucial, as for how a leader think determines his or her attitude towards a problem that directly or indirectly affects them. What will the leader prioritize? Who will he/she protect? Do his/her believe align with what the people want? These are the entire compatibility question that people, no matter how similar their demographical background are with the leader, need to understand and seek answer to.

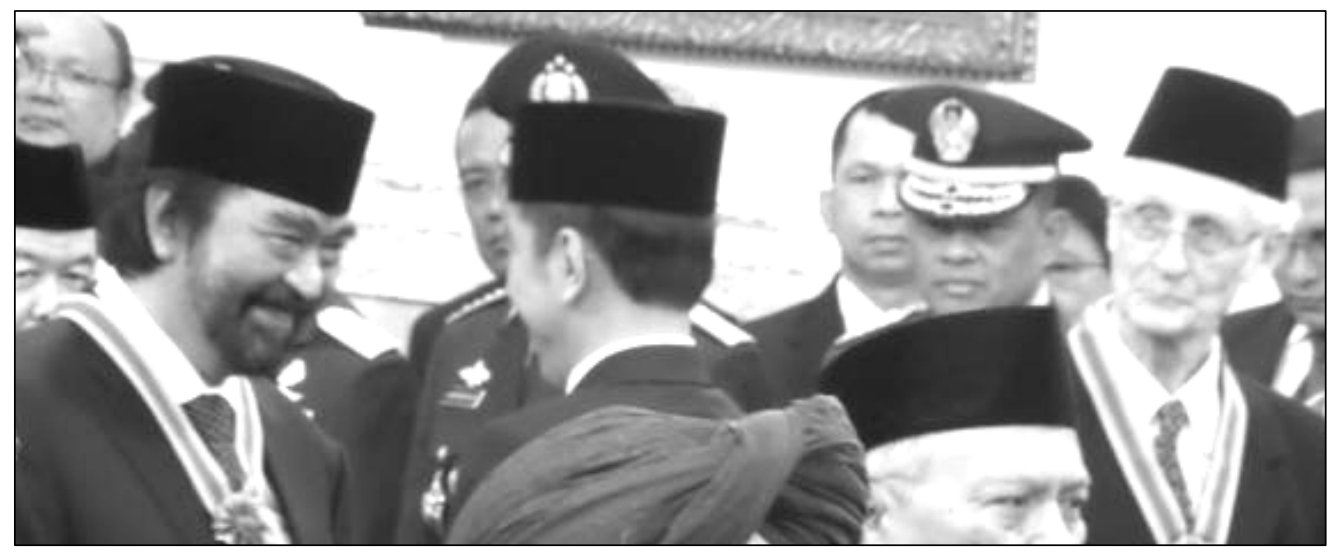

Figure 1. Surya Paloh, President Joko Widodo, General Gatot Nurmantyo (Commander of the Indonesia's Armed Forces), and Franz Magnis-Suseno (Philosopher); zoomed in from Asril (2016)

Cognitive ability is not the only things a leader needs. Personality also plays a key role in determining a leader's characteristic. The general idea is that the personality traits of a leader tend to affect their performance in political roles (Silvester et al., 2014), such as in terms of leading organization, making policies, and even connect with the people. Often employ an "at-a-distance" methodology to assess a political figure's personality, studies suggested that political roles might require the trait of extraversion and openness, with a little demand of neuroticism and conscientiousness (Caprara, Francescato, Mebane, Sorace, \& Vecchione, 2010; Silvester et al., 2014). When we discuss personality, we are not just looking at the politician's abilities and strategies, but also the execution, their intention, and possibility of predicting the outcome of their effort in establishing social changes.

These are often shown from how leaders are campaigning for their programs, talk to their voters, behave, and express their opinion to something even less obvious or visible, like the process of executing a program. The example of the first one can be seen from the distinction between Anies and Ahok, or Surya Paloh and Aburizal Bakrie. How they stand firm on their own belief, criticize each other, and talk about what they are going to do once elected says a lot about the difference in personality. Example of the latter personality display is more complicated. What's important and what's real is what is shown perceived by the public. Thus, it is possible when they are not communicating or even appear in the media, that their personality can be socially constructed and inferred by the general public. This with the politician's value, in turn, will influence the voter's choice (Caprara, Schwartz, Capanna, Vecchione, \& Barbaranelli, 2006)

How media report a politician's figure attitude towards a problem, another person, or the success of executing a policy can subsequently create a personality profile of a politician. Minister Susi's tattoo, President Jokowi's remark about being King Salman's chauffeur, Minister Jonan's attempts to negotiate with Freeport, and even Hary Tanoe's wavering support towards the government: not many behaviors were displayed, not to mention the underlying reasons and context for those phenomena were also unknown. Yet, those events become a cornerstone moment that defines who they are in the eyes of the public. Thus, the personality aspect of a politician can be defined as traits and behavioral tendencies of politicians that are perceived and inferred by the public. This aligns with our approach: the analysis of biographical materials based upon diagnostically relevant content in political-psychological analyses, journalistic accounts, and biographies and autobiographies for the 
Abraham, J., Prayoga, T., \& Takwin, B.

indirect assessment of political leaders (Steinberg, 2005).

Back to Surya Paloh. Previous few passages explain the need to explore a leader's political ability and personality. The reason we are interested in Surya Paloh is his unique stance in political skirmishes in the current state of Indonesia. He is not necessarily an anti-government politician, but also does not agree completely with certain aspects of the regime's policies. His neutral objectivity, unique values, and ambition to establish social change bring a breeze of fresh air and potentially a new option for the people in choosing their new national leader in the upcoming 2019 Presidential Election.

The selection of Surya Paloh as a political figure is profiled based on three reasons. The first, based on objective reasons needed by Indonesia as a nation. The Indonesians need a smart or intelligent show of mass media, and it is, undeniably, on Metro TV, and the top leader is Surya Paloh. Surya Paloh is a prominent figure of the media, having established the Media Group in 1970 with its most prominent media subsidiary, Metro TV in the year 2000. Needless to say, the two bodies of media that he had grown under influence of his principal and virtue. Especially Metro TV, as one of the most renowned television channel in Indonesia; it mostly broadcast news in three languages (Indonesian, English, and Mandarin) and educative/investigative talk show programs like Mata Najwa - http://matanajwa.metrotvnews.com/ —and Kick Andy! — http://www.kickandy.com/. What's notable from the programs (even the satiric comedy talk show Sentilan Sentilunhttp://video.metrotvnews.com/sentilan-sentilun) is the relevancy the shows have with the current state of the nation. Often socio-economy-political issues are discussed with prominent public/political figures, such as President Joko Widodo (Jokowi).

The kind of Indonesians' need can be seen from the testimony of the community as represented by the expression Wirawan (2014), as follows:

"After signing a new petition on the revision of the MD3 Bill, I searched for other petitions, and I was interested to read a counter-petition to close TV M station (Metro TV). However, for TV M, I did not participate in signing the petition Why, I have several reasons. Again, keep in mind; I'm not addicted to television. I have observed, with all its news and talk shows, TV M's efforts to educate and open the horizons of the community are pivotal enough. There is a humanist, psychological talk show in addition to economics and finance as well as politics talk show. Public debate happens repeatedly, hot, but educational. There are video contributions of citizens as well, thus providing opportunities for citizens to participate actively. Although not all the content of citizen submissions are super-meaning that that still needs to be censored as well-it does make the widest possible rooms to as many people as possible. In addition, the individuals who are hosting talk show and the news anchors are people who are skilled in their field. Proven that people who feel the benefits of the aired talks are much more than the people who feel harm. How come do I rarely hear a curse or scolding after a talk show? Or do my eyes not view much? That during the campaign, TV M 'prioritize' one character rather than other figures is a natural thing because the figure is selected and promoted in its political coalition. 'Balancing' is surely much better. But is there any blasphemy or slander in the display? Hmm, when I watched the samples of information, why did I do not look? Maybe I watch less? Do not worry; I'm not paid by TV M for this opinion. I used to go to TV M, for regular weekly nightly broadcasts, but then I was replaced unilaterally, and until now I still consider it to be less professional (but also my fault for not signing the contract). So if I want revenge, I have a reason. However, I still try to objectively see the whole case: D."

Meanwhile, politics is an attempt to achieve the happiness desired by individuals and the public. Getting happiness together can only be achieved through politics and by politics. With politics, self-actualization and optimal function of the individual can take place and the happiness could be attained, at least according to Aristotle (1944). Television in this context is viewed as an influential tool for realizing political goals. Borrowing 
the theory of Psychoanalysis (Lasswell, 1960), political behavior is fundamentally derived from intrapsychic predisposes that are transferred or displaced to public objects. Political behavior done by Metro TV cannot be separated from the psychological state of the leader, in this case, Surya Paloh. Psychological factors indeed influence the political life, so it is urgent to be examined. In a political life that has established patterns, norms, and rules, these psychological factors can be reduced to mutually agree political structures and mechanisms. But in political life that still lacks established patterns, norms, and rules, as happened in Indonesia, those psychological factors cannot be simply reduced, and may even dominate political life. In summary, Metro TV is seen as an "active (political) action" and Surya Paloh is assumed to be the subject who uses television as an instrument to achieve public wealth.

The second, Surya Paloh is the Chairman of the National Democratic Party (Nasdem) who is persistent to build a democratic political life without "dowry" or "repayment" or "high cost" (Ardiansjah, 2017). This is a symbolism of hope against a political party — which has been tainted with its very bad image due to corruptions. This Surya's commitment is consistent with the publication of corrupt political party ranking, where during 2002-2014, the Nasdem Party (established in July 2011) is not included in the 11 parties calculated by its corruption index (Pebriandini, 2015), and throughout 2014-2017, the Nasdem Party belongs to the 5 most not corrupt parties of 10 parties involved in corruption cases until October 2017 (Arrizky, 2017).

The third, Surya Paloh is said to have the opportunity to be nominated as Vice President in the 2019 General Election of Indonesia, after the Nasdem Party officially nominated Jokowi as Indonesian Presidential Candidate, although the electability of Surya Paloh is considered still need to be boosted (JPNN, 2017; Lewuk, 2017; Manangka, 2017a; Nadlir, 2017). Surya Paloh is indeed slightly more well-known in the world of politic nowadays. He is one of the longest-serving members of the Golongan Karya Party (Golkar/The Party of the Functional Groups), having worked for the organization since 1968 until a departure in 2011. The reason for departure is up to debate. Many reasoned that Paloh resorted to forming his own political party, Nasdem, based on already existing community organization because he lost the Golkar's general election to Aburizal Bakrie. However, the real reason might be more complicated. This is where things took a toll on Paloh. Many people were disappointed due to the fact that the National Democratic organization is turning into a political party, seemingly drifting away from its original purposes. However, Paloh reassures his followers that this is not true. This is the point where he distinguishes his party's value from the others.

In many interviews, Paloh stated that his main capital of fighting for Indonesia's restoration is honesty. He felt that his purpose in Golkar has come to an end due to their "irrational" political approach, while Nasdem is focusing on morality and humanity in making a difference for the nation (Rosarians, 2013). Perhaps this is why his party was the first to give the previous incumbent Governor Basuki 'Ahok' Tjahaja Purnama the support to run again for upcoming election. Even after Ahok was being investigated, Paloh and his party were still standing firm on the moral standpoint about supporting the convicted in running again (Syatiri, 2016). Why did Paloh and his party support Ahok? One might argue that the reason behind it is the similarity of personality between the two politicians. Paloh views Ahok as a straightforward, spontaneous, and honest person who brings hopeful promises and carrying mandates that are certain to be fulfilled (Raditya, 2016). His faith in the government especially the incumbent President and previous Jakarta Governor reflected not only his beliefs towards their performance but also his skepticism towards selfish and unfit politicians and policies that are slowing down Indonesia. He stated that there are already too many political actors acting for the sake of themselves (Manafe, 2016). These people are suspected blatantly deny the current government by subtly planning a coup (Aji, 2016). Paloh thinks they should focus on cooperating and give the best for the nation, rather than wasting their energy.

Surya Paloh's statements and political beliefs often give out a sense of urgency about the current state of the nation. Through media and political acts, Paloh tries to restore the value of the Indonesia's founding father, Soekarno, in a way that is both "sincere as a pigeon" and "clever as a snake". The pigeon analogy explains about his action on media, where he presents educative TV shows and gives hard-truth statements that often displease many disreputable politicians in public. Political actors and governmental villains also inhibit his political 
extravaganza. As an individual known for his strong grit in tackling challenges, he also carefully (and boldly) plans his strategy in every political turning point. One example would be as he realizes the public is getting smarter and cannot be fooled by an empty talk from the wishful candidate, he chooses to strongly hold his support for Ahok as a ray of hope that aligns with his idea of restoration.

In arguably chaotic political situations, it is not easy to stay true and consistent with one's own personality and virtue, especially if one is a politician. What influences their leadership and action is what the ultimate goal they want to achieve. For Paloh, this means Indonesia is truly free from the shake of parasitic personnel that infiltrates the nation's independence.

The authors believe that his goal and values do not come from situations that force out, rather it stems from its personality that is reflected in efficacy, consistency, and persistence in representing what is in a mind of a political figure. As Caprara, Barbaranelli, Consiglio, Laura, and Zimbardo (2003) pointed out, modern politics has shifted its focus from the role of the issue to the role of personal attributes to anchor political information. How a politician expresses his persona in dealing current issues matters more to a nation of people that are increasingly interested in what the politician brings to the table. Even more so when there are many parties to put faith onto.

Surya Paloh clearly stands out among other politicians; he is often ambiguously perceived due to complex political interplay. Not because of his status and position, but rather prowess and attitude towards matters. The authors are re-questioning that if he displays the characters of a politician that benefits the nation. This study aims at providing a comprehensive description of Surya Paloh through the examination of his personality and cognitive characteristics in relation to his political role. This investigation contributes in enriching the study of political psychology as a consideration for the public to take political decisions in their daily lives, such as in voting as a manifestation of their political participation. Practically, this study is motivated by the public need to understand political leaders. This study is useful to (1) understand the profile of the personality of political leaders, in this case, Surya Paloh, along with the tendency of his political behavior, (2) to know the strategies and techniques of self-presentation in public in accordance with the personality or character of Surya Paloh, as well as (3) to increase political participation as well as efficacy (Abraham \& Pane, 2014; Abraham \& Viatrie, 2013; Anindya, Leolita, \& Abraham, 2014) of the voters.

\section{Methods}

This study uses the method of "at-a-distance evaluation/measurement", popularized by Winter (2005), as well as Post (2003) in assessing the psychological profile of political figure Bill Clinton and Saddam Hussein. In person measurement is almost impossible, as political figures are often 1) busy, and 2) careful in presenting themselves to the public (Takwin \& Karim, 2004). In addition, in-depth information is often cast aside by rhetorical responses.

This method is part of the psychobiography method. Psychobiography is understood as a significant historical life analysis through the use of psychological theory and research. The goal is to understand people and to uncover the personal motives behind the public action, whether actions involving the making of art or the creation of scientific theories, or the adoption of political decisions. The psychobiography approach assumes that people maintain their psychological characteristics in order to have a meaningful effect on events and results in the real world (Houghton, 2009). With psychobiographical analysis, the personality elements whose indications are found in analyses of the characters' traits and motives are strung together to be coherent with theoretical perspectives. At the same time, the explanations of how traits and motives are organized into personalities are also formulated by considering empirical data from the cues of personality dimensions. The explanation is made to bring together theories and empirical data so that a comprehensive understanding of the characters can be obtained.

The basic assumption of psychobiographical constructions and related psychological profiles (Beliefs and 
Reasoning Patterns, Cognitive Complexity, \& Social Motives) is that political behavior (in order to realize public goals) is influenced by the psychological state of the actor. In the axiom of Greenstein (1969), in ambiguous and unstructured situations, the influence of personal characteristics of political actors is more dominant than situational factors to political behavior. In these circumstances, political studies should also be understood as psychological studies. That is, political studies require psychology as a framework for understanding the behavior of political actors. Psychologically, the range of behavioral areas in the political sphere is very broad, ranging from cognitive processes to understanding political life such as belief, perception, information processing, knowledge, attitudes, and opinions, as well as interpersonal behavior and intergroup behavior. In addition, there are also conflict behaviors, cooperation, decision-making processes, leadership, and leader-follower interactions.

The selection of political figures as a material of psychobiographic study is based on the public need to understand the future leader (President/Vice President). The expected result is the personality profile of the President/Vice Presidential candidate along with the tendency of his/her political behavior. In addition, people can see the strategies and techniques of self-presentation of the personality in public that in accordance with the anticipated personality characteristics of a President/Vice President.

Using the model of personality of McAdams and Pals (2006), this present study yields profiles containing traits and dispositions as well as characteristic adaptations. The phenomenological life story is not acquired because the study did not directly observe and interview and interact with political figures, so it does not intend to obtain an "insider view". This "outsider view" understanding is in line with the studies of personality profiles of political leaders from various cultural backgrounds, suggesting that "remote/at-a-distance assessment" methods could be used to obtain profiles of representative political figures (Feldman \& Valenty, 2001). The assumption of the use of "at a distance evaluation/measurement" is that research on personality through indirect access can be valid and reliable (Winter, 2005). Indirect access is not done not because researchers do not want to try hard, but because the data of political figures' life is not so easy to obtain through psychological testing or in-depth interview, even the plan of taking and publishing the test scores or interviews are often rejected by the figure him/herself.

This present method requires content analysis to search for personality, cognitive, and behavioral pattern that emerge within situational context. The use of content analysis is in line with Winter's expression (2005, p 565), "Content analysis of naturally occurring texts, developed as one of the only ways to study personality at a distance, may also be of use in assessing personality even when we have direct access". The contents analyzed here are both physical and digital, from a biography book (Hisyam, 2014; Manangka, 2014) and various news and columns. Both biographies were chosen because they are the two most comprehensive books on Surya Paloh. Although Haryanto (2002) suspected that Hisyam, who also wrote about Surya Paloh in 2001 (Hisyam, 2001), will "find it difficult to distance themselves and independent of the written figure" but Haryanto also acknowledged that Hisyam's book "speaks volumes about secrets". Using the dramaturgic approach of Goffman (as cited in Bullingham \& Vasconcelos, 2013), the secret of a backstage gives a wealth of perspective to make us understand the identity of a person more fully and "truthfully". Meanwhile, Manangka who worked as long as 13 years in the various media founded by Surya Paloh, although criticized as "not value-free" as a chum of Surya Paloh (Nainggolan, 2016), it can not be denied that he has good expertise in writing biographies. Manangka which shows his self-representation, "Writing honestly and dare to accept the risk of writing, that's what distinguishes me with other writers" (Manangka, 2017b), indeed once wrote a biography of Taufiq Kiemas (Chairman of the Indonesian People's Consultative Assembly during the leadership of President Susilo Bambang Yudhoyono) and Moerdiono (Minister/Secretary of The State, the longest during the leadership of President Soeharto). In the introduction to Manangka's book, Pri Sulisto, the President of the Asia-Pacific Association of Political Consultants stated that "Even if there is subjectivity, Derek Manangka's writings can still be accountable" (Manangka, 2014, p. xix).

In doing the interpretation, the authors make a distinction between social motive and personality. In the 
analysis, it would appear that social motive expression is driven by personality traits (Winter, 2005). Therefore, social motive (together with beliefs and reasoning patterns as well as cognitive complexity) is discussed in Results and then the fundamental, personality traits, discussed further in the Discussion section, so that the coherence seems to follow the analogy of "tree and its roots". In the whole description, the authors did not forget the social context. Using the SWOT (Strength, Weakness, Opportunity, and Threat) approach, the authors see that the Strength and Weakness contained in personality interact with Opportunity and Threat contained in the environment. Therefore, the narrative about Surya Paloh always juxtaposes his personality with the context of the situation. In this case, the situation of political life is an ambiguous situation that makes the role of personality increasingly thick and comes to actualization (Greenstein, 1969). This is to show that in discussing the relationship between politics and personality traits, there are currents in two directions. In addition to the opportunities and threats throughout the lifespan forming the personality (in this context, in the Results section, Psychobiography presented first), the personality also gave birth to the unique opportunities and threats for the character. Nevertheless, it is necessary to remember that although political behavior can be relatively predicted by personality and social motive, the application of the results of this research as a predictor should be closely coupled with the understanding of the developing socio-political situations.

\section{Results}

\subsection{Psychobiography}

Before we present the finding our psychological analysis method, we would like to share the backstory of the man, to provide an elaborative context for understanding the psychology behind Surya Paloh's political persona.

Surya Dharma Paloh was born in Kutaraja, Aceh on 16 July 1951. His father, Daud Paloh, moved around while taking his family during his career as a police. Surya grew up in Medan, not in Aceh. However, he was a member of Tanah Rencong Youth Association (Ikatan Pemuda Tanah Rencong), and he promoted this "double reality" to the public in several occasions, e.g. political campaign (TokohIndonesia, 2012). It is evident that Surya is able to manage his plural identity as an Indonesian and able to show intercultural sensitivity.

According to his oldest brother (as cited in TokohIndonesia, 2012), Surya got a very special attention from his mother, father, and older siblings. Only once that he was heavily punished by his father due to misbehaving. However, at that particular moment, Surya got to understand and inherited his father's discipline and assertiveness. Surya became a reliable and tough person. His father also illustrated that he is a brave person that is willing to take a risk in defending principles that he believes to be true even if it jeopardizes his own safety. It is not surprising that Surya grew up as a responsible person that does not live in a "comfort zone" but also able to expand himself in other aspects of life as long as it is in line with his vision and mission. His father is portrayed to be close individual to his subordinates. This characteristic appears to also be inherited by Surya, in which Surya is known to be egalitarian and can have a very close and intimate relationship with his subordinates.

Surya became a businessman ever since he was a teenager. While running his business, Surya is involved in various organizations. He oftentimes became the coordinator, leader, and chairman of various organizations (Astuti, 2005; Losiyanti, 2015). Spirit of leadership, entrepreneurship, and the urge to be involved in politics has been a part of his life's journey. Surya is a political entrepreneur that is able to perform creative actions with a transformative effect in the political process, determining public and organizational policy. Therefore, it can be concluded that the analytical-synthesis capability of Surya in achieving long-term goals exist.

His passion in developing mass media which he believed as one of the pillars of democracy and public welfare cannot be held back by anyone, even the authority. Surya performed various creative actions, observe all the loopholes and opportunities to support and sustain the kind of media mass that he dreamed of, even if he faced obstacles from authority. Whereas press is not is not a world that he is familiar with in the beginning, 
moreover, there are already many existing competitors. He spent a lot to defend his passion. This shows his persistence coupled with his willingness to sacrifice in order to achieve his vision and mission.

From the description above, it appears that Surya has a high cognitive complexity because he is able to manage various realities without losing his direction and goals. In fact, one step further than that, in an interview with Indonesia2014 (2013), Surya stated, "Great thoughts cannot always be seen by others". This illustrates Surya as a big picture thinker, an imaginative person. Interestingly, this ability is supported by his sociability and belief in collaboration; hence his imagination can be realized in various concrete works such as newspaper, television, mass organization, and political party.

Surya has a rather high empathy. In the moment when he has achieved "everything" (money, political position, big company), Surya's humanitarian side is a side which is fondly remembered by the public. Surya managed various humanitarian organizations. In his biography, it is stated "Surya admits, his idea to greet the people through social program and humanitarian effort also reflects his concern and anxiety-in seeing the many poor people that need attention, assistance, and empowerment to reach an acceptable level of prosperity according to the mission of Indonesia Restoration" (Hisyam, 2014, p. 317).

In line with his entrepreneurial spirit, Surya is a "radical" person, meaning he has the courage to challenge matters which are considered "customary" to achieve conditions that he considered to be ideal. The establishment of Koran Prioritas and Metro TV are prominent examples of his radical spirit. Surya also established the aims clearly. He is purposeful and persistent in achieving them. If there is an obstacle in his journey, he will get rid of the obstacle. If it is a dead end, he will create a new way.

Even though he consistently shows commitment to his goals, he also has spontaneity in making accurate decisions, and it is seen in his actions to help resolve issues quickly during disasters in various regions in Indonesia.

Surya is a demonstrative person, oftentimes by showing his enthusiasm and positive emotional expression in facing or welcoming an offer, rather than a measured person. This is apparent in his transaction with Susilo Bambang Yudhoyono (SBY) and Golkar Party, wherein the end Surya has to bear the "cost" and a bigger disappointment compared to the perceived benefit prior to the transaction (Hisyam, 2014). However, due to the support of his businesses, the issue is not a big deal for Surya, although his disappointment is always aimed at "revenge for positive measures".

\subsection{Beliefs and Reasoning Pattern}

Surya Paloh is an individual who is hard-working, willing to sacrifice himself for what he stands for, able to voice his conscience assertively, and open in his nature; as well as dominant in his actions in various fields, both politics, media, economics, and cultural. We can know this from his consistent characters and actions shown in media.

Surya is a person who is frank in expressing his anger and disappointment to other people or organizations that violate his psychological contract. It refers to the non-written mutual promise or agreement that he makes or has with his affiliated organizations (Juneman, Putra, \& Meinarno, 2014; Ruokolainen, Mauno, Diehl, et al., 2016) — not only his media company and political party but also the country and the people themselves. However, he consistently shows that his anger and disappointment are not motivated by personal revenge. Instead, they are transformed into energy that actualizes his vision and mission that has not been achieved yet. There are elements of doubt in his perception towards the change agents of the country. He clearly defines his organization and identifies him along with all his followers to be in line with their own vision, in line with Soekarno's vision, differing from the others. His belief that the government is not fully abled is not swayed from the start. There are flaws that he recognizes and acknowledges, flaws that he seeks to change himself in order to help the current influenced government. 
He is the person that believes an individual needs to know one's self first prior to introducing one's self to the public in conducting transformation. He revealed several times that he has "finalized himself" prior to having a strong urge to bring major transformation to the people of Indonesia. This shows that his intention and ultimate goal are set right from the start. This could mean that actually, Surya is seeing the opportunity of change for the country. With the right plan and the right action, he actually sees an ideal future of his version for the nation. This can be seen from his words that of resonating and representing his entire party. In this sense, he is the embodiment of the Nasdem party. What his followers are thinking, their beliefs and attitude, and displayed behavior are based on him. He made sure that Nasdem goes along with his vision, and only recruits people with similar if not the same vision as him. Run like an idealistic company, Nasdem is regulated to have one typical "people-siding" voice in approaching almost all national issue, instead of "governmental-sided" one.

As a person who became a businessman starting with zero capital from a young age, Surya believes that physical limitations should not hinder optimism, belief, and confidence. "We may lack money, but we can never lack spirit. We must be rich in spirit," said Surya (as cited in Zulfikar, 2014).

\title{
3.3 Cognitive Complexity
}

Surya believes that professionalism must be put on top of personal interests. His belief is supported by his career history that is filled with pressure from the Indonesia's New Order Government, which he viewed as unprofessional in managing the country and littered with corruption, collusion, and nepotism. This influences his approach to looking at many political and economic issues. Although most of the issues are inter-related, he did not fail to differentiate and identify core problems of each issue. He often suggests solutions or points out problems straight to the heart. He is the type to come up with an ideal solution to prevent future problems whilst solving current one.

Surya has a high cognitive complexity due to his background and vast network of business, social, and politics. The combination of those three makes him able to be called as a political entrepreneur. According to political scientist Francis Fukuyama, political entrepreneur is someone who convinces the people that he or she can represent them, understand their problems, and ultimately solve those (Fukuyama \& Koulinka, 2017). This means he is able to create creative actions that have a transformative impact in the political process, determining political and organizational policy for the members of the organizations that he is affiliated with. He is a person that thinks he knows what's best for the organization that he is working for. Not necessarily effective now, his policies and ideas often work for long-term purposes. One example to support this argument is through his confidence to lead Golkar Party (Kompas, 2009a). His history in the past also shows his cognitive complexity:

\begin{abstract}
"In the New Order era, Surya Paloh (is) .... unique or controversial. For being in the midst of such era having a very phobia to Soekarno, Surya Paloh growing in the era secretly admired the enemy of the New Order. It is not easy for a figure like Surya Paloh to play a two-legged politics like that. Being a proponent of Soekarno's ideology (secretly) but at the same time being a collaborator with the New Order leader, who is a regime of opponents of Soekarno. This attitude is not an easy political maneuver." (Sulisto, as cited in Manangka, 2014, p. xx)
\end{abstract}

He has the political leadership resources and ability to utilize various opportunities to experiment carefully. The result is new political formulas and new political institutions that are nearly perfectionistic and aligned with his ideology. He is not a political chameleon but always appeared as a political survivor with his critical individual image and steadfastness in his principles and ideals. This is also inherited by his organization showed solidarity in protecting one of their members, Viktor Laiskodat. Previously, Viktor has stated that some political party such as Partai Gerindra/Great Indonesia Movement Party, Partai Demokrat/Democratic Party, and Partai Amanat Nasional/The National Mandate Party, along with some others are trying to change Indonesian's ideology by endorsing Khilafah — belief that Muslim should be led by Muslim and abide the law of Syariah-diverting the country's ideological direction away from Pancasila. Pressured to prosecute Viktor, Surya 
and Nasdem decided that they will do nothing in support of his innocence (Sutari, 2017). Some view that this incident is an attempt to dismantle and discredit the party's power, in light of Surya's support and potentially becoming a candidate in upcoming Presidential Election in 2009. Nasdem's fraction member Johnny G. Plate has also stated that Surya has been a subject of slander for the past years, but they choose to endure and did not report it (Riso, Iqbal, \& Harni, 2017).

\title{
3.4 Social Motives
}

By using David McClelland's (1965) theoretical framework, the most apparent social motive in Surya is his need for power. This is the capacity of receiving pleasures out of having an impact on the others (Köllner \& Schultheiss, 2014). Even though Surya repeatedly states that for him, the position is not important compared to the advancement of the country, it cannot be denied that he has a big desire to become one of the leader-or at least play a major role in impactful and revolutionary changes for the country.

This need most likely comes from his youth where he is used to leading various businesses, social and political organizations. If he' $\mathrm{d}$ found an obstacle, he is able to face it. If the obstacle is too great, he is able to create a new channel as his new instrument of struggle. He earnestly develops and takes care of the new channel. One of the greatest examples is the establishment of Nasdem Party, an organization which Surya created after serving Golkar for 43 years; in whichever since its birth, has been prepared with infrastructure, social network, human resource quality, management of party, to become the ruling party (Hisyam, 2014, p. 273).

The newly established Nasdem Party is able to grow as the only party that can grab approximately $7 \%$ of the people's vote during the 2014 Indonesia General Election. The Nasdem Party wing organizations, from the youth group, women group, and labor group, become a community network under the leadership of Surya. Surya's high need of power is apparent from the change in his life orientation after 50 years, from altruistic to being involved in practical politics, with the primary consideration of being able to do more for the people and the nation. Need for power of Surya Paloh also appeared when he became Chairman of the Golkar Party Advisory Board:

\begin{abstract}
"The result of the 2005 Golkar Party National Congress in Bali made Surya Paloh a powerful figure in the party bearing the banyan tree. He became the Chair of the Advisory Board. In the past, that position could only be held by President Soeharto. Although there is a provisional view that the position is no longer as strategic as in Soeharto's heyday, it does not mean that Surya has no agendas and calculations ... He must have had political calculations. Surya always thinks positive. He has a philosophy that whether or not a strong position depends on the person who occupies that position." (Manangka, 2014, p. 230)
\end{abstract}

The second social motive of Surya Paloh is the need for achievement. That is the need for success in terms of competition with some standard of excellence (Zahid \& Shahbaz, 2016). Interestingly, need for achievement is often the common predictor of becoming a businessman (Carland, Carland, \& Stewart, 2015). It shows a person's tendency to prove his or her best in their area of passion and importance. Surya said, "We are not a weak competitor" (GatraNews, 2014). This is proven since his youth and since his involvement in the press and business world. When Koran Prioritas that he led was restraint, his spirit of struggle was transformed into Media Indonesia. Surya was even able to reach the position as the Chairman of the Advisory Board for Golkar although for decades he never became part of Golkar's executive board. He then realized that his aspiration for the Restoration of Indonesia will never be accommodated in Golkar, hence he established Nasdem. He gave all of his efforts, time, energy, thoughts, and everything that he possesses to fight for his ideals.

The third social motive of Surya is his need for affiliation. This is apparent when he established the National Democratic (Nasional Demokrat) Mass/Community Organization, Surya requested that an inventory along with lobbying to 100 figures of inter-profession, inter-party, inter-university, as well as inter-tribe and religion, to discuss the idea of establishing the mass organization. Similarly, previously, even at the age of 22, Surya as the 
Abraham, J., Prayoga, T., \& Takwin, B.

Chairman of DPD HIPMI (Regional Leadership Council of Indonesian Association of Young Businessmen) North Sumatera was able to invite Vice President Adam Malik to visit his office. Need for affiliation is also demonstrated by Surya in his social behavior pattern:

"I consider Surya Paloh as a man who gives treatment to every person, to every colleague, or to his subordinates with differentiated concepts and approaches.” (Manangka, 2014, p. 309)

The three social motives of Surya Paloh are summarized in Table 1.

Table 1

Personality Aspects: Strength and Weakness of Surya Paloh as a Political Leader

\begin{tabular}{|c|c|c|}
\hline Salient Aspects & Strength & Weakness \\
\hline Visionary & $\begin{array}{l}\text { Able to see far into the future as well as } \\
\text { able to create breakthrough to accelerate } \\
\text { the achievement of the vision }\end{array}$ & $\begin{array}{l}\text { The vision may not be immediately } \\
\text { understood by others rather it is } \\
\text { understood later in the end. }\end{array}$ \\
\hline Need for achievement & $\begin{array}{l}\text { Relentless in fighting for his ideals and } \\
\text { quickly learns from obstacles and failure } \\
\text { that he suffered. } \\
\text { Based his struggle not solely on spirit, } \\
\text { but also on scientific thought } \\
\text { ("progressive theory"; Hisyam, 2014, p. } \\
215 \text { ) }\end{array}$ & $\begin{array}{l}\text { Surya's influence is considered } \\
\text { dangerous especially for those parties } \\
\text { with different affiliation (Hisyam, } \\
\text { 2014, p. } 42 \text { ) }\end{array}$ \\
\hline Need for power & $\begin{array}{l}\text { Able to gather national figures and } \\
\text { common people to support his } \\
\text { organization; } \\
\text { Able to bring those he leads to jointly } \\
\text { become renowned and foremost. }\end{array}$ & $\begin{array}{l}\text { Can make other people with more or } \\
\text { less power than him feel they have } \\
\text { been stepped over. }\end{array}$ \\
\hline $\begin{array}{l}\text { Critical-cynical, } \\
\text { inspirational }\end{array}$ & $\begin{array}{l}\text { Able to fight for his ideals by keeping a } \\
\text { sufficient distance from those parties } \\
\text { viewed as authoritative. }\end{array}$ & $\begin{array}{l}\text { Can be viewed as traitors by those } \\
\text { parties that do not understand the logic } \\
\text { of his ideals. }\end{array}$ \\
\hline $\begin{array}{l}\text { Creative, } \\
\text { non-conventional but } \\
\text { ethical }\end{array}$ & $\begin{array}{l}\text { Able to perform political movement } \\
\text { effectively through non-traditional } \\
\text { manners in dilemmatic political areas } \\
\text { without violating the law and ethics. }\end{array}$ & $\begin{array}{l}\text { His creativity often occurred as a } \\
\text { reaction toward the disappointment } \\
\text { that he experienced. }\end{array}$ \\
\hline Decision maker & $\begin{array}{l}\text { Able to make a quick, spontaneous, and } \\
\text { appropriate decision as well as } \\
\text { anticipative measures in an emergency } \\
\text { situation. }\end{array}$ & $\begin{array}{l}\text { The spontaneity and the speed of his } \\
\text { decision making have the potential of } \\
\text { violating the general principles of } \\
\text { bureaucracy namely must consider all } \\
\text { relevant factors, including officials that } \\
\text { become his subordinate along with his } \\
\text { decision. }\end{array}$ \\
\hline
\end{tabular}

\section{Discussion}

As a political entrepreneur, Surya is a person that is not glued to traditional norms even though he respects them. He does not abide unconditionally by parties that he viewed as an authority. This is mentioned repeatedly that as an exponent of Golkar does not mean that he had to blindly follow all of Golkar's policy. However, the salient trait of Surya is his toughness in which he tends to position and present himself as a strong and dominant leader. This is clearly seen in the description by Usamah Hisyam (2014, p. 242) regarding Surya's attitude toward the Hary Tanoesoedibjo's exit and the opposition of Nasdem's Secretary-General Ahmad Rofiq:

"Surya understood that responding to such actions will only create an illusion that they have a big power that must be taken into account. Whereas, Surya clearly understands, that their power is meaningless. As an experienced politician for 43 years, and experiencing the ups and downs of various conflicts, Surya viewed those movements as non-existent ... Small ripples always occurred in political dynamics ...." 
It cannot be denied that his experience of being disappointed by authority, as he stated, "I rise and fall, then pressured, excluded" (Hisyam, 2014, p. 226), is accompanied by his twisting experience in fighting for his ideal brought him to the view that this world is savage, and this is reflected in his hard and sharp speeches in describing the issues of this country.

In measuring personality traits of Surya Paloh, the authors borrow the framework of the Big Five personality traits (McCrae \& Costa, 1997). The authors do not analyze each personality traits in general sense, rather by specific facets of each interpretation of events and behavioral responses record.

\subsection{High Conscientiousness, High Dutifulness, High Achievement Striving, High Self-discipline}

Surya emphasizes the importance of moral obligations related to the position, job title, and occupation. He shows objection to events and procedures that are not carried out accordingly, resulting in adverse consequences. $\mathrm{He}$ is not hesitant to respect and accept results if procedures and results are carried out in accordance with the system. The event of proof is as follow:

"Enggartiasto Lukita suggested that Surya should do something to save the party and his companion, Akbar Tanjung which was involved in Bulloggate: 'Please help, don't keep it running in the news.' Upon hearing that request, Surya answered with a high voice: 'How is it possible that you ask Media Indonesia and Metro TV to not broadcast the case, whereas other media are broadcasting it? Which logic did you use... You must know, Gar. In this democratic era, I, as the owner, am no longer able to intervene the editorial staff. This is a code of ethics that must be upheld.'” (Hisyam, 2014, p. 74)

In addition, in response to Golkar's 2009 Chairman Election, Paloh criticized that the events did not go as he expected. According to him, there were many delays happened in the event that allegedly affected the end result, by which he lost to Aburizal Bakrie (Kompas, 2009b). However, he also showed an intention to respect the decision of the election, if it is constituent and rightful.

Surya has a need for personal achievement. He also has a sense of direction, as well as persistent in achieving his goals. For example, this was shown when Surya Paloh was about to publish the Tabloid of Politics of Realitas as a substitute for the Newspaper of Prioritas banned by the New Order Government, a story that showed Paloh's persistence:

"I am reminded of the event in August 1998. Three friends of Surya Paloh, i.e. Nasruddin Hars, Panda Nababan, and Widjanarko Puspoyo, with no-holds-barred-steps resigned carrying a number of human resources amidst the preparation for the publication of the Political Tabloid of Realitas .... Surya Paloh did not waver and called me into his room. 'This tabloid must be published. Prove it to them, without them we can. Do not think whether this tabloid would be sold or not. Even if only me and you who read this tabloid, but we have to prove our ability, said Surya Paloh with serious facial expression. The political tabloid of Realitas finally came out in October 1998.” (Manangka, 2014, p. 7)

He also came back by becoming Presidential Candidate of Nasdem Party; this establishes that he is willing to start over from scratch after failing (and disappointed) at another place. The events of proof are as follow:

"Facing the Golkar Party presidential candidate convention, Surya prepares himself seriously and earnestly. He formed a supporting team, and also diligent in socializing, attending Convention at the Provincial level. For Surya, the Golkar Party Presidential Candidate National Convention is a golden bridge in realizing his ideals and obsession ... is an opportunity to deliver him as the number one person in the Republic in a democratic way." (Hisyam, 2014, p. 80) 
"I am grateful in my life. Because my parent knows, I struggle from point zero ... You must know, I worked really hard day and night without a cent of financial capital. I have only one main capital: honesty." (Hisyam, 2014, p. 225)

Surya's step also seems "apolitical" by playing the role as a "neutral" media person (Astuti, 2005), but in the end, the mass media that he owned becomes a forum that accommodates his aspiration of coming into power through the Nasdem Party. According to Shambazy (2014), the neutrality of the press is indeed a utopia; what might be achieved is the independence (but not neutrality) of the press. What is meant by the independence of the press such as the one undertook by Surya Paloh is "the attitude of independence and firmly choosing the path or way the people want" (Shambazy, 2014), or in the expression of Manangka (2014), "a genuine cognizance, or siding, or affirmative positioning".

At a more superficial level, the high conscientiousness of Surya Paloh was shown by Surya's concern for the appearance of journalists from his newspaper:

"Surya clearly emphasizes the importance of performance. Journalists should not appear haphazardly. When Newspaper Prioritas just came up, the first thing he did was to buy a shirt and tie for some senior reporter. Photographer Bobby Waworuntu, whose posture is as tall as Surya Paloh, gets a basket of safari suit, which was then an expensive suit. Then when he bought a majority share of Vista magazine, specifically, Surya Paloh asked for clothes designers to create work uniforms for all employees .... Two years later, while managing Media Indonesia, Surya had dared to provide car facilities to senior editors and journalists through vehicle ownership program through installment (Car Ownership Program).” (Manangka, 2014, p. 68)

\subsection{Low Agreeableness, Low Compliance}

Surya is a person capable and can endure getting involved in conflict even against superior parties (Golkar, New Order) to defend his principles (even though he is a member of Golkar). The events of proof are as follow:

"As a member of People's Consultative Assembly from Golkar for 2 periods (10 years), Surya increase his effort in developing democracy in the New Order authoritarian era by establishing Koran Prioritas as the voice of democracy. Furthermore, he also transformed Media Indonesia as 'reincarnation' of Koran Prioritas. 'Arrogance of power must be fought,' he said." (Hisyam, 2014 , p. 50, 55)

"I am a cadre of Golkar, but Media Indonesia does not belong to Golkar." (Hisyam, 2014, p. 56)

"Ever since the beginning, Surya who is nominated as a presidential candidate in Golkar Party convention has stated his attitude in private to Akbar Tanjung (the Chairman of Golkar Party) that he disagrees if Akbar becomes a participant of the convention." (Hisyam, 2014, p. 79)

"'So, what is wrong if I held a campaign of anti-Corruption, Collusion, and Nepotism, and all the thieves, manipulators wherever they are in this country must be excluded, including those in Golkar Party. If Mr. Akbar feels he never perform corruption, yes, why should he be afraid?' said Surya." (Hisyam, 2014, p. 96)

In addition, although against corruption, he is not necessarily an ally to the commission, as he did not agree completely with how the Corruption Eradication Commission worked in investigating his right-hand man. $\mathrm{He}$ criticized the Indonesian Corruption Eradication Commission (KPK) for focusing on small cases by investigating Rio Capella, a member of Nasdem party that received IDR 200 million slush funds from North Sumatra Governor.

At an interpersonal level, low agreeableness of Surya Paloh was also shown when he did not just follow 
advice that may seem to be in his favor. For example:

"After meeting and talking for a few minutes, the guest (a businessman) and Surya quickly became familiar .... Finally, the guest ventured by giving advice to Surya. This entrepreneur strongly believes in fengshui. The science of fengshui teaches about what gives luck and which brings misfortune. His advice to Surya is to have his mustache and beard shaved flat. 'If you shave them, all sustenance will flow more smoothly and much to you. The mustache and the beard block out all the sustenance,' he said. The meeting took place at the time of Surya Paloh media business was still limited in the world of newspapers and had not penetrated into the world of broadcasting (television) .... The businessman is still adding more. 'By allowing the mustache and beard to grow so dense, the strong and violent impression of Surya Paloh becomes so strong. The impression must be removed so that Surya Paloh get more friends'... But what happened, it turns out Surya just smiled and laughed a little.” (Manangka, 2014, p. 76)

\subsection{High Extraversion, High Assertiveness, High Excitement Seeking}

Surya Paloh is a person that is able to speak bluntly, showing control and domination as well as power in expression even while facing authority. This is also shown towards one of his respected political leader, President Joko Widodo, as shown in the following story:

“Although a supporter, Surya Paloh once criticized Jokowi's governance in front of the media. Jokowi's political promise in his campaign, Nawa Cita (Nine National Priority Agenda/Ideals), was not fulfilled after 1 year of being president.” (Ahmad, 2015)

The other events of proof are as follow:

"In Rakernas FKPPI in Malang on February 1983, Surya persuaded the meeting participants to abject the Ali Moertopo's proposition concerning establishing Soeharto as the Father of Development. In addition, at the podium in KNPI (Komite Nasional Pemuda Indonesia/Indonesia's Youth National Council) National Meeting forum, Surya loudly and without a text asked Abdul Gafur (KNPI advisor) to intervene in the election of KNPI Chairman.” (Hisyam, 2014, p. 48-49)

"In a meeting, Surya jokingly satirized President Susilo Bambang Yudhoyono/SBY: 'Aburizal Bakrie has already 'helped' you a lot. From the Lapindo case, you have also helped him in the Newmont case, and you have also helped him become the Chairman of the Golkar Party. You have exercised all of your power to help Aburizal Bakrie that ended with a minor defeat for me,' said Surya, while looking sharply at President SBY who looked stunned of Surya's word." (Hisyam, 2014, p. 157)

By involving himself in a very dynamic politics, in time when Surya reach old age, this clearly shows that Surya has a need for stimulations from his surroundings. He cannot stay put in a literal and symbolic meaning (fighting for his ideals). The event of proof is as follow:

"Upon reaching the age of 50, Surya states that he decided to no longer be involved in politics and daily business activities, and promised to become an altruistic philanthropist. But instead, it is after he is 50 years old that he came back to increasingly rowdy practical politics. He does not want to stop in just becoming an altruist." (Hisyam, 2014, p. 64-65)

In addition, in action that is considered dangerous and not normally done by political figures, Surya stayed true to his value and top priority: the public. He risked lives, reputation, and resources of his organizations for 10 Indonesian. This is shown when Surya Paloh and his organizations formed a team of negotiators to free 10 Indonesian captured by Abu Sayyaf (Kami, 2016). This action is considered dangerous and not normally done by 
Abraham, J., Prayoga, T., \& Takwin, B.

political party leaders.

The excitement seeking character is also confirmed by the choices Surya took that were not merely survival let alone in comfort, as follows:

"The failure of Surya Paloh in Bali is a story about the weight of an investor's struggle in the media world. If Surya Paloh is only looking for financial gain, surely it is not the media business that should be his choice .... If the media character possessed by him impressed us greatly, it does not happen by chance anyway. The character is formed by the influence of Surya's patriotism. Without it, Surya Paloh may have since long abandoned the media business." (Manangka, 2014, p. 28)

\subsection{High Openness, High Aesthetics}

Surya shows his concern for culture and arts, in which he impressed the stakeholders so much that he was presented with various awards. Surya obtained an award as Tatar Sunda Resident from the Sunda Elderly in Tatar Sunda Cultural Festival in Alam Sentosa, Bandung Regency, West Java; he is an Honorary Member of Merpati Putih martial arts school; he also obtained Tuanku Johan Pahlawan (Sir Johan Hero) Award, for his concern in protecting and developing the culture of Minangnese (Astuti, 2005; Merdeka, n.d.).

High openness was also demonstrated by Surya Paloh in shaping the "personality of the newspaper" he founded, Prioritas. There are two things that become the indication. First is the placement of Editorial consistently entitled Selamat Pagi Indonesia (Good Morning Indonesia)—which echoes the media opinion raising democracy and human rights—on the front page of the daily:

"Surya himself who initiated the importance of an opinion presented on the front page of the newspaper, so readers can immediately understand what is being thought by the media management .... 'The Editorial is the editorial board view. So why should that view be hidden inside? Who forbids the Editorial to be placed on the front page?,' so the comments as well as the rhetoric of Surya Paloh. So it was the idea of Surya Paloh which became an antithetical step as well as a breakthrough.” (Manangka, 2014, p. 29, 95)

Secondly, Surya Paloh allowed daily reporters of Media Indonesia, who were under control of him, to be a member of various political parties:

"One time Surya invited DPP PDI (Central Executive Board of Partai Demokrasi Indonesia/Indonesian Democratic Party). The party members' group came with the Chairman, Soerjadi, to Media Indonesia office .... Surya gave his idea that Media Indonesia's journalists were allowed to be a member of political party. Of course, the idea was warmly welcomed. Surya Paloh also recommended that DPP PDI to use Media Indonesia without hesitation to deliver the party's programs. The same thing he did to the DPP PPP (Central Executive Board of Partai Persatuan Pembangunan/United Development Party). At that time the General Chairman was Ismael Hassan Metareum, an Acehnese origin .... Why did Surya Paloh adopt such a policy? He wanted to give a kind of political learning, i.e. the Indonesian people must believe that different political choices are reasonable. 'Different' does not mean must be enemy or opponent. Differences exist only in dialectics. For Surya himself, having subordinates (journalists) who spread in different political parties has many benefits. Especially if his men become the core cadres of the parties. From the point of interest of political lobbying, through his men, Surya Paloh can enter to the heart of the party.” (Manangka, 2014, p. 226-227)

\subsection{High Neuroticism, High Anxiety, High Angry Hostility}

Surya's anxiety regarding his capability can be seen clearly, by him describing his "inner battle", and his 
inner voice that changes from morning-noon-to night time. This indicates that there is a strong trait of neuroticism in Surya; especially that expression coincides with the word "honesty". The events of proof are as follow:

“Reporter of Men's Obsession magazine: 'But really, what are your capitals for running as a presidential candidate?' Surya: 'There is a capital in me which is honesty. Is honesty enough? The answer is no. Is there capability? I doubt it. Anyhow, I have to stay frank. Then there is the inner battle in the morning, my heart says that I am able to lead this nation. In the afternoon, it says I'm not capable. Night time, I am worthy of running as an alternative presidential candidate for the people. Finally, at midnight, I decided: I have to be able.” (Hisyam, 2014, p. 86)

"Surya frankly revealed that his heart is truly hesitant when deciding his resignation from the Golkar Party.” (Hisyam, 2014, p. 262)

In addition, he chooses to believe but is not $100 \%$ sure with government's decision and standpoint on political matters. The unpredictability of the course of events creates uncertainty within Surya himself. In a few instances, Surya has shown his support by asking people to support the government, especially the President. However, he is also the one to criticize and expressed doubts towards government's policies and political decisions.

It is apparent that Surya is not able to restrain his tendency to express his anger and other related matters, such as frustration and bitterness. However, he is able to control his expression although it appears from his murmured that he truly is angry. It is true that in the case of Jusuf Kalla, he is angry based on his principles because the dichotomy of Javanese-Non Javanese does not exist for him in the context of NKRI (Negara Kesatuan Republik Indonesia/The Unitary State of the Republic of Indonesia). However, his basic tendency for anger is clearly shown. Not everybody whose principles are violated by other parties expressed it through anger. The events of proof are as follow:

"Surya was no longer confident when SBY offered him to collaborate with SBY-Boediono government to improve the national economic condition. Moreover, Surya felt that SBY's offer is just a lips service ... 'Ah, please,' said Surya in his thought. 'Please, Mr. President. I don't need to be involved again, 'said Surya, which startled SBY.” (Hisyam, 2014, p. 166)

"A year prior to the 2009 Presidential Election, Surya had been disappointed by Jusuf Kalla (JK)'s attitude. He even rebukes the Chairman. It is because, in the middle of the anniversary celebration of the Demokrat Party in September 2008, JK made a statement which was virally reported in the media, that he cannot become a presidential candidate because he is not Javanese. 'I was angry with him,' Surya recalled. He answered: yes, sorry, sorry. Apparently, he blurted out.” (Hisyam, 2014, p. 172)

"Surya tried to dampen the anger and prestige that is churning in his heart facing the situation where the SIUPP (Press Publication Permit) of Media Indonesia will be revoked by the Minister of Information in 1990 ... Surya took a deep breath while slamming the letter on his work desk. His face looked infuriated. His heart was relieved while mixed with anger." (Hisyam, 2014, p. 379)

"Suddenly Surya turned emotional, 'That bastard Sudomo? Who does he think he is, putting a restraining order?'” (Hisyam, 2014, p. 382)

However, Surya's high neuroticism also marks his high confidence or firmness towards the values he holds (cf. Zacharopoulos, Lancaster, Maio, \& Linden, 2016). This was demonstrated by Surya Paloh, as follows:

“Chief of Political Social Staff Indonesian Armed Forces Headquarters, Lt. Gen. Syarwan 
Abraham, J., Prayoga, T., \& Takwin, B.

Hamid .... asked Surya Paloh for his media not to give 'stage' to Megawati (Chairman of Indonesian Democratic Party) and Gus Dur (Chairman of General Committee of Nahdlatul Ulama) .... 'I just told Syarwan Hamid, if we are hopeless in the diplomacy effort, I think the solution that I can offer to you is to provide two bullets,' said Surya commenting on Syarwan Hamid's stressing request. 'Two of those bullets are for two. One was used in the morning to finish off Gus Dur and the other was used at night to shoot Mega. Done,' added Surya Paloh .... Syarwan Hamid was shocked and his expression changed illustrating that Syarwan was very angry. Surya does not care .... Their meeting ended in a graceless atmosphere." (Manangka, 2014, p. 55-56)

\subsection{Leadership}

The author summarized the areas of strength and potential of Surya Paloh's leadership in Table 2.

Table 2

Leadership Competency Analysis: Strength and Potential Improvement

\begin{tabular}{|c|c|c|}
\hline Competency & $\begin{array}{c}\text { Strength when Becoming } \\
\text { A Nation Leader }\end{array}$ & $\begin{array}{c}\text { What Needs to Be Improved when } \\
\text { Elected as A Nation Leader }\end{array}$ \\
\hline \multicolumn{3}{|c|}{ Innovation } \\
\hline $\begin{array}{l}\text { Creating new and valuable } \\
\text { ideas as well as using that } \\
\text { idea to develop new or } \\
\text { better process, method, } \\
\text { system, product, and } \\
\text { service. }\end{array}$ & $\begin{array}{l}\text { Able to create the idea that attracted the } \\
\text { attention of many people as well as applying } \\
\text { it effectively. } \\
\text { E.g. Golkar Presidential Candidate } \\
\text { Convention, a new model of election, is } \\
\text { Surya's idea. Similarly, the idea for Nasdem } \\
\text { which attracted the sympathy of prominent } \\
\text { national figures like Sri Sultan, Anies } \\
\text { Baswedan, etc. The establishment of Metro } \\
T V \text { as the first News TV in Indonesia is also } \\
\text { an indicator of an innovative idea. }\end{array}$ & $\begin{array}{l}\text { The fast-moving innovation of idea has the } \\
\text { risk of appearing to be inconsistent, thus it } \\
\text { does not obtain further support. } \\
\text { E.g. When the Nasdem Party (as a political } \\
\text { party) was established, the exponent of } \\
\text { Nasdem (as a mass organization) resigned } \\
\text { one by one. }\end{array}$ \\
\hline \multicolumn{3}{|c|}{ Risk Taking } \\
\hline $\begin{array}{l}\text { Bold decision-making } \\
\text { while facing risk and } \\
\text { uncertainty; creating } \\
\text { radical recommendations } \\
\text { and supporting their } \\
\text { implementation. }\end{array}$ & $\begin{array}{l}\text { A political entrepreneur with the background } \\
\text { as a businessman which is ready to invest } \\
\text { heavily in obtaining his vision. }\end{array}$ & $\begin{array}{l}\text { His perfectionism and altruism has the } \\
\text { potential of taking risks that are "wasteful" } \\
\text { E.g. 'Transaction' case with Susilo } \\
\text { Bambang Yudhoyono (mentioned in } \\
\text { Results - Psychobiography section) which } \\
\text { brought major resentment for Surya Paloh }\end{array}$ \\
\hline \multicolumn{3}{|c|}{ Transformational Leadership } \\
\hline $\begin{array}{l}\text { Visionary, providing a } \\
\text { good role model, } \\
\text { developing a solid group, } \\
\text { high-performance } \\
\text { expectation, support } \\
\text { toward a subordinate, } \\
\text { intellectual stimulation. }\end{array}$ & $\begin{array}{l}\text { The substance of his vision of Restoration of } \\
\text { Indonesia (Trilogy, i.e. People's Prosperity, } \\
\text { A Nation of Dignity, Strong Country) which } \\
\text { repeats and strengthens Soekarno's vision } \\
\text { (Trisakti, i.e. Politically sovereign, } \\
\text { Economically self-reliance, and Culturally } \\
\text { strong in Indonesian character.) makes it easy } \\
\text { for him to be accepted by the people, even by } \\
\text { the youth. E.g. the acceptance by the youth is } \\
\text { supported by the establishment of Garda } \\
\text { Pemuda (Guardian of Youth). } \\
\text { His knowledge of Indonesia political and } \\
\text { economic landscape which he honed through } \\
\text { decades of being a political and economic } \\
\text { actor can be integrated to actualize his vision } \\
\text { of Indonesia. } \\
\text { Surya is able to establish solid groups in the } \\
\text { form of mass organization wings and able to } \\
\text { provide intellectual and motivational } \\
\text { stimulation which is able to mobilize those } \\
\text { wings effectively. }\end{array}$ & $\begin{array}{l}\text { The term 'Restoration' still sounds foreign } \\
\text { in the ears of the common people and } \\
\text { requires further socialization and } \\
\text { operationalization. }\end{array}$ \\
\hline
\end{tabular}


Table 2 ...continued

\begin{tabular}{lll}
\hline \multicolumn{1}{c}{ Competency } & \multicolumn{1}{c}{$\begin{array}{c}\text { Strength when Becoming } \\
\text { A Nation Leader }\end{array}$} & $\begin{array}{c}\text { What Needs to Be Improved when } \\
\text { Diversity Appreciation } \\
\text { Elected as A Nation Leader }\end{array}$ \\
\hline $\begin{array}{l}\text { Respect for the various } \\
\text { differences. }\end{array}$ & $\begin{array}{l}\text { Respecting differences, as well as supporting } \\
\text { the diversity based on the Pancasila (the state } \\
\text { ideology). }\end{array}$ & $\begin{array}{l}\text { Easy to launch harsh criticism, even anger, } \\
\text { toward parties that violate the diversity } \\
\text { principle thus appearing unsympathetic for } \\
\text { some parties meaning it is } \\
\text { counterproductive if the aim is persuading } \\
\text { other parties with the position of opposition } \\
\text { to appreciate diversity. }\end{array}$ \\
\hline $\begin{array}{l}\text { The concern in fulfilling } \\
\text { the needs of the people in a } \\
\text { way that satisfies them. }\end{array}$ & $\begin{array}{l}\text { Goes to the grass root, digging aspiration } \\
\text { from the people. } \\
\text { Able to leverage research and development } \\
\text { agency to process the feedback from the } \\
\text { people and to formulate policies based on the } \\
\text { result of that process. }\end{array}$ & $\begin{array}{l}\text { Monitoring and evaluating the } \\
\text { sustainability of fulfilling the needs of the } \\
\text { people requires special attention and } \\
\text { efforts. }\end{array}$ \\
\hline
\end{tabular}
result of that process.

\begin{tabular}{|c|c|}
\hline $\begin{array}{l}\text { Knowledge of background, } \\
\text { orientation, experience, } \\
\text { culture and other } \\
\text { countries; creating an } \\
\text { atmosphere that makes } \\
\text { other people feel accepted } \\
\text { and invited. }\end{array}$ & $\begin{array}{l}\text { Having a global insight thus able to compare } \\
\text { the development of Indonesia to other } \\
\text { countries based on the resources and outcome } \\
\text { and becoming material in formulating of how } \\
\text { Indonesia should be. } \\
\text { In addition, he is able to garner international } \\
\text { power to be involved in his vision. E.g. "You } \\
\text { see the development of infrastructure and } \\
\text { economy in European countries is very fast. } \\
\text { Even though they do not have vast natural } \\
\text { resources like our country. But why is it that } \\
\text { our country is so far behind?" (Hisyam, } \\
2014, \text { p. xiv) }\end{array}$ \\
\hline
\end{tabular}

\section{Conclusion}

Perhaps one word that describes Surya Paloh the best is an idealist. From this root trait of him, stem the cognitive, personality, and leadership pattern emerges when he hustles in the political jungle. He is a person with high determination, having inherited the will of the founding father to bring changes towards the country. His idealism is shown by his disappointments and anger towards many occurrences that went the opposite of what he had expected or would have done. However, he seems to be the type that will pull through (a political survivor) no matter what it takes-even apparently violating his promise-to achieve his goal; a trait that political entrepreneurs have. Being a leader is a must, for only himself he could depend on to implement changes that align with his ideology.

Surya is a dutiful person, as he respects what the country has to offer, and is the type to follow the system, rather than fighting against it. However, it is not uncommon that we see he loses his temper when the things went out of his ideological line. He is someone that establishes and represents himself well to the public. Not the one seeking popularity, but also try his best to make a good impression; mainly to endorse his idea and opinion to the public.

Being an experienced politician and businessman, Surya often has ideas on how to implement and manage changes. Although it is not uncommon either that those ideas often fade away without a thorough support. On how he establishes his images in public, Surya fits the category of a charismatic leadership. He continuously emphasizes his focus on transforming the country into a corruption-free and tolerant nation.

This present study supports the proposition of Abraham and Prayoga (2017) that Indonesian laypersons need to be empowered by the community of psychology scientists, among others through the study's publication in this International Journal of Research Studies in Psychology, by leveraging their psychological capacity to 
Abraham, J., Prayoga, T., \& Takwin, B.

understand and take effective political action, e.g. via Presidential Election 2019, for recreating their fate in better directions. The limitation of this study is that this present study is still less to integrate political speeches of Surya Paloh as the material for composing his political psychological profiling. The authors still gave priority to (1) the biographies written by professional senior journalists, as well as (2) digital media information-in avoiding social desirability bias contained in the anticipated rhetorical speeches. The testimonials and information chosen by the authors (as social psychologists) have been carefully selected to describe the political decision-making process and shared values communication that Surya Paloh undertakes.

\section{References}

Abraham, J., \& Pane, M. M. (2014). The mediating role of social competition identity management strategy in the predictive relationship between susceptibility to social influence, Internet privacy concern, and online political efficacy. Lecture Notes in Computer Science, 8407, 492-499 (Information and Communication Technology-EurAsia Conference). Berlin, Heidelberg: Springer.

Abraham, J., \& Prayoga, T. (2017). Indonesian students' representation on psychology and social change: Challenge for curriculum progression. Open Journal of Social Sciences, 5(8), 122-135. https://doi.org/10.4236/jss.2017.58010

Abraham, J., \& Rufaedah, A. (2014). "Theologization" of psychology and "psychologization" of religion: How do psychology and religion supposedly contribute to prevent and overcome social conflicts? Procedia Environmental Sciences, 20, 516-525. https://doi.org/10.1016/j.proenv.2014.03.064

Abraham, J., \& Viatrie, D. I. (2013). Apakah kreativitas dan sikap terhadap ilmu ekonomi meramalkan partisipasi politik mahasiswa? Peran mediasi efikasi politik pada mahasiswa di Malang, Jawa Timur [Are creativity and attitude toward economics able to predict students' political participation? The mediating role of political efficacy among students in Malang, East Java]. Makara Seri Sosial Humaniora, 17(2), 109-125. https://doi.org/10.7454/mssh.v17i2.2960

Ahmad, H. M. (2015, October 20). Surya Paloh: Saya beri nilai 6,5 untuk setahun kerja Jokowi [Surya Paloh: I give 6.5 for Jokowi's one working year]. CNN Indonesia. Retrieved from http://www.cnnindonesia.com/politik/20151020022715-32-85932/surya-paloh-saya-beri-nilai-65-untuksetahun-kerja-jokowi/

Aji, Y. B. (2016, November 22). Surya Paloh akan lawan upaya kudeta [Surya Paloh will be against the coup attempt]. MetroTVNews. http://news.metrotvnews.com/politik/dN6dEPpk-surya-paloh-akan-lawan-upaya-kudeta?fb_comment_i $\mathrm{d}=1253741351315834 \_1254800127876623$

Anindya, S., Leolita, V., \& Abraham, J. (2014). The role of psychology in enhancing public policy: Studies on political apathy and attachment to the city in Indonesia. International Journal of Research Studies in Psychology, 3, 99-114. https://doi.org/10.5861/ijrsp.2014.922

Ardiansjah, N. (2017, August 29). Ikuti Langkah Nasdem 'politik tanpa mahar', pengamat: langkah PSI harus diapresiasi [Following Nasdem 'politics without a dowry', expert observers: PSI steps should be appreciated]. Retrieved from https://merahputih.com/post/read/ikuti-langkah-nasdem-politik-tanpa-mahar-pengamat-langkah-psi-har us-diapresiasi

Aristotle. (1944). Politics (H. Rackham, Trans.). Cambridge, MA: Harvard University Press.

Arrizky, R. (2017, October 1). Daftar parpol dengan kader terbanyak diciduk KPK [The list of political parties with the most cadres was caught by Indonesian Corruption Eradication Commission]. DetikNews. Retrieved from https://news.detik.com/infografis/d-3665720/daftar-parpol-dengan-kader-terbanyak-diciduk-kpk

Asril, S. (2016). Presiden Joko Widodo memberikan tanda kehormatan kepada tokoh pers nasional, Surya Paloh, di Istana Negara, Kamis (13/8/2015) [President Joko Widodo gave honorary medal to national press figure Surya Paloh at the State Palace on Thursday (August 13, 2015)] [Online image]. Retrieved from http://nasional.kompas.com/read/2015/08/13/11561421/Presiden.Jokowi.Anugerahkan.Tanda.Kehormat 
an.kepada.46.Tokoh

Astuti, S. I. (2005). Surya dalam berita [Surya in the news]. MediaTor, 6(1), 109-115.

Bullingham, L., \& Vasconcelos, A. C. (2013). 'The presentation of self in the online world': Goffman and the study of online identities. Journal of Information Science, 39(1), 101-112. https://doi.org/10.1177/0165551512470051

Caprara, G. V., Schwartz, S., Capanna, C., Vecchione, M., \& Barbaranelli, C. (2006). Personality and politics: Values, traits, and political choice. Political Psychology, 27(1), 1-28. https://doi.org/10.1111/j.1467-9221.2006.00447.x

Caprara, G., Barbaranelli, C., Consiglio, C., Laura, P., \& Zimbardo, P. G. (2003). Personalities of politicians and voters: Unique and synergistic relationships. Journal of Personality and Social Psychology, 84(4), 849-856. https://doi.org/10.1037/0022-3514.84.4.849

Caprara, G., Francescato, D., Mebane, M., Sorace, R., \& Vecchione, M. (2010). Personality foundations of ideological divide: A comparison of women members of Parliament and women voters in Italy. Political Psychology, 31, 739-762. https://doi.org/10.1111/j.1467-9221.2010.00780.x

Carland, J. A. C., Carland, J. W., \& Stewart, W. H. (2015). Seeing what's not there: The enigma of entrepreneurship. Journal of Small Business Strategy, 7(1), 1-20.

Dragoni, L., Oh, I. S., Tesluk, P. E., Moore, O. A., VanKatwyk, P., \& Hazucha, J. (2014). Developing leaders' strategic thinking through global work experience: The moderating role of cultural distance. Journal of Applied Psychology, 99(5), 867-882.

Eksan, M. (2011, July 9). Nasdem sebagai ormas dan partai politik [Nasdem as mass organizations and political parties]. Kompasiana. Retrieved from http://www.kompasiana.com/moch.eksan/nasdem-sebagai-ormas-dan-partai-politik_5500f5a0a333115b 74512448

Feldman, O., \& Valenty, L. O. (Eds.). (2001). Profiling political leaders: Cross-cultural studies of personality and behavior. Westport, CT: Praeger/Greenwood. Chicago: Markham.

Fukuyama, F., \& Koulinka, N. (2017, January 20). Donald Trump and the return of class: An interview with Francis Fukuyama. Open Democracy. Retrieved from https://www.opendemocracy.net/francis-fukuyama-natalia-koulinka/donald-trump-and-return-of-class-i nterview-with-francis-fukuyama

GatraNews. (2014, March 28). Surya Paloh, Ketua Partai Nasdem: Kita bukan pesaing yang lemah [Surya Paloh, Chairman of the Nasdem Party: We are not a weak competitor]. GatraNews. Retrieved from https://www.gatra.com/kolom-dan-wawancara/49801-surya-paloh,-ketua-partai-nasdem-kita-bukan-pes aing-yang-lemah.html

Greenstein, F. I. (1969). Personality and politics: Problems of evidence, inference, and conceptualization. Chicago: Markham Publishing Company.

Haryanto, I. (2002, January 7). PK Ojong dan Surya Paloh [PK Ojong and Surya Paloh]. Pantau. Retrieved from https://www.pantau.or.id/?/=d/103

Hisyam, U. (2001). Editorial kehidupan Surya Paloh: Perjalanan 50 tahun (1951 - 2001) [Editorial life of Surya Paloh]: 50 years of travel]. Jakarta, Indonesia: Yayasan Dharmapena Nusantara.

Hisyam, U. (2014). Surya Paloh-Matahari restorasi: Sang ideolog [Surya Paloh-The sun of restoration: The ideologue]. Jakarta: Dharmapena Citra Media.

Houghton, D. P. (2009). Political psychology: Situations, individuals, and cases. New York: Routledge.

Indonesia2014. (2013). Pikiran-pikiran besar tidak selamanya dilihat orang [Great thoughts are not always considered by people]. Retrieved from http://www.saifulmujani.com/blog/2013/09/24/\%E2\%80\%9Dpikiran-pikiran-besar-tidak-selamanya-dili hat-orang\%E2\%80\%9D

Jain, A. K., \& Jeppesen, H. J. (2013). Knowledge management practices in a public sector organisation: The role of leaders' cognitive styles. Journal of Knowledge Management, 17(3), 347-362. https://doi.org/10.1108/JKM-11-2012-0358

Jensen, F., \& Asmarini, W. (2015, December 4). UPDATE 2-Freeport Indonesia head says speaker of parliament 
Abraham, J., Prayoga, T., \& Takwin, B.

tried to extort shares. Reuters. Retrieved from

http://www.reuters.com/article/indonesia-freeport-probe-idUSL3N13T1WX20151204

JPNN. (2017, July 18). Buat yang setuju Jokowi-Surya Paloh di pilpres 2019, klik! [For you who agree on the duet between Jokowi and Surya Paloh in the 2019 presidential election, click!]. JPNN. Retrieved from https://www.jpnn.com/news/buat-yang-setuju-jokowi-surya-paloh-di-pilpres-2019-klik

Juneman, J., Putra, F., \& Meinarno, E. A. (2012). Kompatibilitas keutamaan karakter dengan nilai-nilai pancasila: perspektif kontrak psikologis dan kontrak sosial [The compatibility between character virtues and the Pancasila values: A perspective of psychological contract and social contract]. Prosiding SNaPP: Sosial, Ekonomi, dan Humaniora, 3(1), 253-260.

Kami, I. M. (2016, March 2). Nasdem: Surya Paloh inisiatif bentuk tim negosiator bebaskan 10 WNI [Nasdem: Surya Paloh has initiative to form the negotiating team to free the 10 Indonesian citizens]. DetikNews. Retrieved from https://news.detik.com/berita/3201464/nasdem-surya-paloh-inisiatif-bentuk-tim-negosiator-bebaskan-10 -wni

Köllner, M. G., \& Schultheiss, O. C. (2014). Meta-analytic evidence of low convergence between implicit and explicit measures of the needs for achievement, affiliation, and power. Frontiers in Psychology, 5, 826. https://doi.org/10.3389/fpsyg.2014.00826

Kompas. (2009a, October 7). Surya Paloh: Saatnya pimpin Partai Golkar [Surya Paloh: Time to lead Golkar Party]. Kompas. Retrieved from http://internasional.kompas.com/read/2009/10/07/15343522/surya.paloh.saatnya.pimpin.partai.golkar

Kompas. (2009b, October 8). Surya Paloh: Ada ketidakberesan dalam Munas Golkar [Surya Paloh: There are disruptions in the Golkar National Congress]. Kompas. Retrieved from http://nasional.kompas.com/read/2009/10/08/14192617/surya.paloh.ada.ketidakberesan.dalam.munas.g olkar

Lasswell, H. D. (1960). Political character and constitution. Psychoanalysis and Psychoanalytic Review, 46, $1-18$.

Lewuk, D. (2017, July 20). Pengamat: Surya Paloh lebih berpeluang dampingi Jokowi di pilpres 2019 [Expert observer: Surya Paloh is more likely to accompany Jokowi in 2019 presidential election]. NetralNews. Retrieved from http://www.netralnews.com/news/politik/read/89323/pengamat.surya.paloh.lebih.berpeluang.da

Losiyanti, M. (2015). Analisis framing berita mundurnya Surya Paloh dari Partai Golkar di Viva.co.id [Framing analysis of the news of the withdrawal of Surya Paloh from Golkar Party in Viva.co.id]. eJournal Ilmu Komunikasi, 3(1), 1-16.

Manafe, I. N. (2016, November 22). Surya Paloh: Masak terus menerus jadi aktor? [Surya Paloh: Is it logical to continuously being an actor?]. TribunNews. Retrieved from http://www.tribunnews.com/nasional/2016/11/22/surya-paloh-masak-terus-menerus-jadi-aktor

Manangka, D. (2014). Surya Paloh: Melawan arus menantang badai [Surya Paloh: Fighting the waves and challenging the storms]. Jakarta, Indonesia: Gramedia Pustaka Utama.

Manangka, D. (2017a). Jokowi-Paloh di 2019? [Jokowi and Paloh in 2019 presidential election?]. EraMuslim. Retrieved from https://www.eramuslim.com/berita/nasional/derek-manangka-jokowi-paloh-di-2019.htm

Manangka, D. (2017b). Catatan tengah Derek Manangka: Melamar jadi Menteri Koordinator [Mid note of Derek Manangka: Applying to be Coordinating Minister]. Konfrontasi. Retrieved from https://konfrontasi.com/node/106737

McAdams, D. P., \& Pals, J. L. (2006). A new Big Five: Fundamental principles for an integrative science of personality. American Psychologist, 61(3), 204-217. https://doi.org/10.1037/0003-066X.61.3.204

McClelland, D. C. (1965). Toward a theory of motive acquisition. American Psychologist, 20(5), 321-333. https://doi.org/10.1037/h0022225

McCrae, R. R., \& Costa, P. T., Jr. (1997). Personality trait structure as a human universal. American Psychologist, 52(5), 509-516. https://doi.org/10.1037/0003-066X.52.5.509

Merdeka. (n.d.). Surya Paloh. Retrieved from https://profil.merdeka.com/indonesia/s/surya-paloh/ 
Political psychology of Indonesian political figure: A case of a political who is not hesitant in paving a new way

Nadlir, M. (2017, November 16). Nasdem masih rahasiakan calon pendamping Jokowi di Pilpres 2019 [Nasdem still keeps Jokowi's potential companion in the 2019 presidential election]. Kompas. Retrieved from http://nasional.kompas.com/read/2017/11/16/14452601/nasdem-masih-rahasiakan-calon-pendamping-jo kowi-di-pilpres-2019

Nainggolan, S. (2016, January 29). Salah pikir atas Derek Manangka (Tanggapan atas artikel Jokowi dan Rini Terlibat "Love Affair"?) [Misunderstanding over Derek Manangka (Response to Manangka's article entitled Jokowi and Rini are Involved in "Love Affair"?)]. CakraWarta. Retrieved from https://www.cakrawarta.com/salah-pikir-atas-derek-manangka-tanggapan-atas-artikel-jokowi-dan-rini-t erlibat-love-affair.html

Pebriandini, I. (2015, June 24). Analisa sederhana: Kejanggalan data KPK Watch [Simple analysis: Data anomaly of KPK Watch]. Kompasiana. Retrieved from https://www.kompasiana.com/ndhaandini/analisa-sederhana-kejanggalan-data-kpk-watch_54f7c3bba33 $\underline{311 \mathrm{c} 27 \mathrm{~b} 8 \mathrm{~b} 4 \mathrm{cfb}}$

Post, J. M. (Ed.). (2003). The psychological assessment of political leaders: With profiles of Saddam Hussein and Bill Clinton. Michigan, US: University of Michigan Press.

Raditya, I. N. (2016, March 21). Surya Paloh ungkap alasan NasDem dukung Ahok [Surya Paloh revealed the reason why NasDem supports Ahok]. Tirto. Retrieved from https://tirto.id/surya-paloh-ungkap-alasan-nasdem-dukung-ahok-o1r

Riso, N., Iqbal, M., \& Harni, D. (2017, August 7). Nasdem: Surya Paloh juga sering difitnah, tapi kami diam tak laporkan [Nasdem: Surya Paloh is also often slandered, but we are silent and do not report]. Kumparan. Retrieved from https://kumparan.com/nadia-riso/nasdem-surya-paloh-juga-sering-difitnah-tapi-kami-diam-tak-laporkan

Rosarians, F. (2013, December 2). Ini alasan Surya Paloh hengkang dari Golkar [This is the reason Surya Paloh left Golkar]. Tempo. Retrieved from https://m.tempo.co/read/news/2013/12/02/078533852/ini-alasan-surya-paloh-hengkang-dari-golkar

Ruokolainen, M., Mauno, S., Diehl, M. R., Tolvanen, A., Mäkikangas, A., \& Kinnunen, U. (2016). Patterns of psychological contract and their relationships to employee well-being and in-role performance at work: Longitudinal evidence from university employees. The International Journal of Human Resource Management, 1-24. https://doi.org/10.1080/09585192.2016.1166387

Shambazy, B. (2014). Dari jasa boga ke industri demokrasi [From catering to the industry of democracy]. In Manangka, D., Subroto, H., \& Aditya, W. (Eds.), Surya Paloh: Melawan arus menantang badai [Surya Paloh: Fighting the waves and challenging the storms] (pp. xxxiii-xxxv). Jakarta, Indonesia: Gramedia Pustaka Utama.

Silvester, J., Wyatt, M., \& Randall, R. (2013). Politician personality, Machiavellianism, and political skill as predictors of performance ratings in political roles. Journal of Occupational and Organizational Psychology, 87(2), 258-279. https://doi.org/10.1111/joop.12038

Steinberg, B. S. (2005). Indira Gandhi: The relationship between personality profile and leadership style. Political Psychology, 26(5), 755-790. https://doi.org/10.1111/j.1467-9221.2005.00443.x

Sutari, T. (2017, August 4). PKS dan PAN minta Surya Paloh copot Viktor Laiskodat [PKS and PAN asked Surya Paloh to discharge Viktor Laiskodat]. CNN Indonesia. Retrieved from https://www.cnnindonesia.com/politik/20170804143547-32-232497/pks-dan-pan-minta-surya-paloh-co pot-viktor-laiskodat/

Syatiri, A. S. (2016, November 16). Ahok tersangka, Surya Paloh tegaskan Nasdem tidak tarik dukungan [Ahok becomes the suspect, Surya Paloh affirms Nasdem not to take off support for him]. Kompas. Retrieved from

http://megapolitan.kompas.com/read/2016/11/16/15224981/ahok.tersangka.surya.paloh.tegaskan.nasde m.tidak.tarik.dukungan

Takwin, B., \& Karim, N. L. (Ed.). (2004). Sang kandidat: Analisis psikologi politik lima kandidat Presiden dan Wakil Presiden RI Pemilu 2004 [The candidate: Analysis of the political psychology of five candidates of President and Vice President of the 2004 Indonesia General Election]. Jakarta, Indonesia: Penerbit 
Buku Kompas.

Tashandra, N. (2016a, November 27). Soal rencana pergantian Ketua DPR, ini komentar Surya Paloh

[Concerning the replacement plan of the Chairman of House of Representatives, this is Surya Paloh's comment]. Kompas. Retrieved from http://nasional.kompas.com/read/2016/11/27/18174241/soal.rencana.pergantian.ketua.dpr.ini.komentar.s urya.paloh

Tashandra, N. (2016b, November 23). Soal wacana pergantian Ketua DPR, Ketua DPP Nasdem sorot masalah moral [Concerning the discourse of the replacement of House of Representatives Chairman, Nasdem Central Executive Board Chairman highlights the moral issue]. Kompas. Retrieved from http://nasional.kompas.com/read/2016/11/23/13245251/soal.wacana.pergantian.ketua.dpr.ketua.dpp.nas dem.sorot.masalah.moral

TokohIndonesia. (2012). Surya itu cermin dari Daud Paloh [Surya is the reflection of Daud Paloh]. Retrieved from https://www.tokohindonesia.com/biografi/article/285-ensiklopedi/315-pembawa-suara-masa-depan/favo rites?start $=3$

Winter, D. G. (2005). Things I've learned about personality from studying political leaders at a distance. Journal of Personality, 73(3), 557-584. https://doi.org/10.1111/j.1467-6494.2005.00321.x

Wirawan, H. (2014, July 14). Tadi setelah menandatangani petisi baru soal revisi RUU MD3, saya telusuri petisi-petisi yang lain. Saya tertarik membaca petisi tandingan untuk menutup stasiun televisi M. Namun, untuk TV M, saya tidak turut berpartisipasi menandatangani petisi. Mengapa? Saya punya beberapa alasan [After signing a new petition on the revision of the MD3 Bill, I searched for other petitions, and I was interested to read a counter-petition to close TV M station (Metro TV). However, for TV M, I did not participate in signing the petition Why, I have several reasons]. [Facebook status update]. Retrieved from https://m.facebook.com/story.php?story_fbid=10152304174264751\&id=521889750

Zacharopoulos, G., Lancaster, T. M., Maio, G. R., \& Linden, D. E. (2016). The genetics of neuroticism and human values. Genes, Brain and Behavior, 15(4), 361-366. https://doi.org/10.1111/gbb.12286

Zahid, G., \& Shahbaz, K. (2016). Citizenship and need of achievement: A comparison of English curricula from Pakistan, Hong Kong and UK. Academic Research International, 7(2), 79-90.

Zulfikar, M. (2014, February). Surya Paloh: Kita boleh kurang uang tapi tak boleh kurang semangat [Surya Paloh: We may have less money but we should not lack spirit]. TribunNews. Retrieved from http://www.tribunnews.com/pemilu-2014/2014/02/22/surya-paloh-kita-boleh-kurang-uang-tapi-tak-bole $\underline{\text { h-kurang-semangat }}$ 